\title{
Makna Psikologis dan Teologis \\ Keberadaan Manusia Menurut Lukas 10:27
}

\author{
Zevania Venda Andaline \\ Universitas Pelita Harapan Surabaya \\ E-mail: zevaniavendaa@gmail.com
}

\begin{abstract}
The difference in viewpoints between dichotomous and trichotomic understandings will certainly not subside. The dichotomous believer has an emphasis on the visible and invisible. On the other hand, those who want to describe human existence in more detail are often called trichotomists. Yet if you want to sort out the existence of humans will be more than just 3 parts.
\end{abstract}

Keywords: Dichotomous, Trichotomic, Human

\section{LATAR BELAKANG}

Manusia adalah makhluk hidup yang unik. Manusia adalah makhluk hidup dengan segala potensi yang dimiliki. Manusia terdiri dari tubuh, jiwa dan roh. Manusia diciptakan memiliki kemampuan berpikir dan memiliki emosi. Begitu uniknya manusia, banyak ilmu pengetahuan ingin meneliti mengenai kehidupan manusia. Para filsuf bergumul dengan hal itu. Tak ketinggalan para sosiolog pun mencoba untuk menjawabnya. Para psikolog dan psikiater tengah meneliti mengenai keunikan dari manusia dan para pakar etika juga aktivis social memiliki minat yang sama.

Bisa dilihat dan dipahami bahwa membahas tentang manusia begitu menariknya luar biasa. Tak habis-habisnya dari semua penulisan buku dan berbagai macam film serta program televisi membahas tentang manusia. Semua tertarik pada perilaku manusia, apa, siapa, dan bagaimana manusia itu daripada hal yang lainnya.

Secara umum semua orang pasti setuju bahwa manusia memiliki sifat badaniah (yang kelihatan) dan sifat yang tidak badaniah (tak kelihatan). Sifat badaniah dari manusia adalah tubuhnya, sedangkan sifat yang tidak badaniahnya adalah jiwa dan rohnya.Manusia dalam konteks Psikologi menjelaskan bahwa manusia terdiri dari tubuh dan jiwa. Banyaknya teori yang bermunculan tetap saja ahli psikologi setuju bahwa manusia hanya terdiri dari tubuh dan jiwa. Tubuh menurut ahli psikologi terdiri dari sistem biologis, yang

terdiri dari organ, jaringan, sel dan jaringan ikat. Jiwa adalah bagian yang abstrak. Namun jiwa ini yang menjadi penggerak dan pengatur segala perilaku seseorang. Perilaku tersebut dapat berupa sesuatu yang dapat diamati dan tidak diamati secara langsung.

Sementara itu para ahli psikologi kurang sependapat bahwa psikologi sama dengan ilmu jiwa, walaupun ditinjau dari arti kata kedua istilah yang sama. Secara harafiah psikologi adalah ilmu kejiwaan, namun untuk rentang waktu yang relatif lama, ketika psikologi masih bagian dar ifilsafat. Namun lambat laun psikologi diartikan sebagai ilmu mempelajari pikiran kemudian berubah lagi menjadi behavior (ilmu yang mempelajari tingkah laku). Maka dari itu para ahli psikologi sependapat bahwa, psikologi merupakan studi ilmiah mengenai perilaku organisme. Pada dasarnya, mereka mencoba mencari tahu apa yang membuat manusia berdetak dan bagaimana pikiran manusia bekerja.Di dalam memahami dan menjelaskan perilaku tersebut, psikologi menggunakan beberapa pendekatan seperti pendekatan neurobiogist, pendekatan perilaku, pendekatan kognitif, pendekatan psikoanalisis, dan pendekatan fenomenologis. 
Di dalam konteks Teologi, unsur manusia dibedakan menjadi materi dan bukan materi. Ada satu kesatuan dari dua hali tu. Namun, ada perbedaan pandangan dalam susunan kejiwaan manusia apakah makhluk rangkap dua atau tiga.

Mereka yang beranggapan bahwa jiwa dan roh itu sama atau satu hakikat disebut golongan dikhotomis. Mereka yang beranggapan bahwa jiwa dan roh itu tidak sama disebut golongan trikhotomis. Gereja Barat umumnya menerima pandangan dikhotomik, sedangkan gereja Timur umumnya menerima trikhotomik.

Tidak hanya sampai situ, ada pula penjelasan dari Strong dalam bukunya Systematic Theology mengenai struktur moral manusia yang terdiri dari kecerdsan berpikir, sensibilitas, dan kehendak, bersama dengan kemampuan untuk membedakan serta memberikan dorongan yang disebut dengan hati nurani.

Berkhof menuliskan bahwa natur manusia dalam Alkitab itu dikotomis. Perbedaan yang ada dikarenakan pengaruh filsafat Yunani. Orang yang berpegang pada pandangan trikotomi berusaha mencari dukungan dalam Alkitab, dengan paham ada dua bagian konstituen dari natur manusia sebagai tambahan pada elemen material atau elemen yang lebih rendah yaitu jiwa dan roh. Antitesisnya adalah tubuh dan jiwa sekali pun dalam pengertian Perjanjian Baru, tidak ditemukan dalam Perjanjian Lama.

Laidlaw memaparkan bahwa antitesisnya jelasya itu tentang yang rendah dan yang lebih tinggi, yang duniawi dan yang surgawi, yang hewani dan Ilahi. Kesatuan ini bukan hanya selalu dua elemen yang bersatu menjadi kesatuan yang serasi, "manusia menjadi makhluk hidup" dalam Kej. 2:7. Perjanjian Lama menunjukan elemen yang lebih rendah dalam diri manusia seperti daging, debu, tulang, usus, ginjal. Elemen yang lebih tinggi seperti roh, jiwa, hati, pikiran.

Manusia terdiri dari dua bagian merupakan suatu hakikat yang tidak dapat disangkal. Manusia adalah kesatuan dari materi dan non materi, dua aspek yang data dibedakan. Kematian jasmani dilukiskan sebagai perpisahan badan dan roh (Yak. 2:26).

Dikotomi Alkitab berbeda daripengajaran Plato bahwa tubuh dapat lenyap tetapi jiwa berada di surga yang terdiri dari ide atau suatu bentuk yang murni. Dikotomi
Alkitab berbeda secara radikal dari dualisme Plato. Dikotomi Alkitab tidak mengajarkan bahwa tubuh adalah penjara bagi jiwa yang dilepaskan pada saat kematian serta kembali kesurga untuk diinkarnasikan lagi ketubuh yang lain.

Lain halnya dengan Trikhotomi, pandangan ini seperti yang diketahui manusia terdiri dari badan, jiwa dan roh (roh lebih unggul daripada jiwa dan roh serta jiwa lebih unggul dari pada tubuh). Pendangan ini mengkaitkan tubuh dengan diri sendiri, jiwa kepada dunia tetapi roh pada Allah.

Roh dan kerohanian hendaknya dibina, sedangkan kejiwaan dan badan hendaknya ditekan. Dalam hal ini Ryrie mengomentari bahwa cara membedakan semacam ini adalah upaya trikhotomi untuk menarik analogi antara Tritunggal dari Allah dan manusia.

Oknum dalam Tritunggal adalah sama rata, namun manusia tidak demikian adanya. Lalu kepada Pribadi yang mana dari Allah Tritunggal itu bagian manusia mau disamakan? Sehingga baik secara logika, analogi maupun Alkitabiah, trikotomi tidak dapat dipertahankan.

Ryrie menambahkan manusia adalah kesatuan yang kaya ragam. Berbagai segi dari materi dan non-materi berpadu membentuk manusia yang utuh. Manusia memantulkan berbagai aspek dari keseluruhan. Mereka bisa saja memiliki fungsi yang sedemikian sama namun tetap dapat dibedakan satu dengan yang lain. Bukan bagian yang terlepas, melainkan mereka adalah aspek-aspek, segisegi, wajah-wajah dari keseluruhan. Ada bermacam-macam segi-segi rohani manusia (non materi) seperti jiwa, roh, hati, hati nurani (kesadaran), pikiran, daging, kehendak.

Dari banyaknya penjelasan yang ada, menurut Ichwei dalam bukunya menjelaskan bahwa Alkitab dengan jelas tidak mengajar adanya perbedaan dikhotomis maupun trikhotomis.

Sebaliknya Alkitab memandang manusia sebagai satu pribadi yang rumit dan tegang. Manusia adalah satu pribadi yang utuh dan tidak terbagi menjadi dua (dikhotomi dan trikhotomi). Manusia adalah satu pribadi yang rumit sebab memiliki roh, tubuh, dan daging di dalam satu nyawa / jiwa (Kej.2:7). Sedangkan pribadi yang tegang karena unsurunsur itu dipersatukan di dalam dirimanusia 
dan saling bertentangan satu sama lain (Roma 7:15-26).

Pendapat yang lainya itu dari Heath dalam bukunya menjelaskan pengenalan tentang manusia dan lingkungannya harus berpangkal pada penjelasan Sang Pencipta, terutama dari Kitab Kejadian . Manusia diciptakan menurut gambar dan rupa Allah (Kej. 1:26-27). Gambar Allah berhubungan dengan aspek manusia dan bukan secara jasmani. Allah menciptakan manusia baik adanya dengan aspek materi dan aspek nonmateri. Aspek materi ini berwujud dan hanya ada saat seorang manusia hidup secara jasmani. Sedangkan aspek non-materi ini adalah yang tak berwujud seperti jiwa, roh, kecerdasan, kehendak, hatinurani, dan lain-lain.

Bila membahas mengenai roh ini adalah bagian non-materi dalam diri manusia. Roh inilah yang berhubungan dengan perjalanan manusia dengan Allah. Sepert dalam Amsal 20:27 berkata "Roh manusia adalah pelita TUHAN, yang menyelidiki seluruh lubuk hatinya."

Sehingga berdasarkan pengamatan penulis, penelitian ini masih jarang diteliti dan diperdalam bila ditunjukkan dari psikologi juga. Judul atau topic ini menarik untuk diteliti lebih lanjut karena frasa segenap hatimu, segenap jiwamu, segenap kekuatanmu, segenap akal budimu dalam Lukas 10:27 mengutip dalam Ulangan 6:5. Lukas mengutip Perjanjian Lama dan diurai lagi.

Ulangan pasal 6 merupakan lanjutan dari Ulangan pasal 5 saat di mana Musa berbicara kepada seluruh orang Israel mengenai kesepuluh Firman. Kasih kepada Allah merupakan hal yang utamad alam Ulangan pasal 6. Orang Isarel harus mengikuti perintah TUHAN untukmengasihi Allah dengan segenap hati, dengans egenap jiwa dan dengan segenap kekuatan. Hal ini menarik dimanad alam Lukas 10:27 menuliskan dengan menambahkan frasa segenap akal budimu. Dapat dilihat dari latar belakang juga, mengapa Lukas menuliskan frasa tersebut yang ditujukan kepada orang Yunani. Maka perlu dilihat dan dikaji dengan benar.

\section{RUMUSAN MASALAH}

Berdasarkan latar belakang permasalahan yang telah dibahas di atas, maka yang menjadi masalah pokok dalam penelitian ini adalah sebagai berikut:Pertama, apa makna psikologis dari frasa segenap hatimu, segenap jiwamu, segenap kekuatanmu, segenap akal budimu dalam Lukas 10:27?

Kedua, apa makna teologis frasa segenap hatimu, segenap jiwamu, segenap kekuatanmu, segenap akal budimu dalam Lukas 10:27?

\section{TUJUAN PENELITIAN}

Pembahasan dan penelitian mengenai frasa segenap hatimu, segenap jiwamu, segenap kekuatanmu, segenap akal budimu, memilik itujuan:

Pertama, untuk mengetahui makna psikologis dari frasa segenap hatimu, segenap jiwamu, segenap kekuatanmu, segenap akal budimu dalam Lukas 10:27.

Kedua, untuk mengetahui makna teologis dari frasa segenap hatimu, segenap jiwamu, segenap kekuatanmu, segenap akal budimu dalam Lukas 10:27.

\section{MANFAAT PENELITIAN}

Pertama, bermanfaat untuk memberikan penjelasan mengenai makna psikologis dari frasa segenap hatimu, segenap jiwamu, segenap kekuatanmu, segenap akal budimu dalam Lukas 10:27.

Kedua, bermanfaat untuk memberikan penjelasan mengenai makna teologis dari frasa segenap hatimu, segenap jiwamu, segenap kekuatanmu, segenap akal budimu dalam Lukas 10:27.

Perbedaan sudut pandang antara pemahaman dikotomis dan trikotomis memang tak akan ada surutnya. Yang memercayai secara dikotomis memiliki penekanan pada yang kelihatan dan yang tidak kelihatan.

Di sisi lain yang ingin memerinci keberadaan manusia lebih detil sering disebut trikotomis. Padahal kalau mau dipilah-pilah keberadaan manusia akan lebih dari sekadar 3 bagian saja.

Kajian psikologis tanpa memfokuskan pada kejiwaan bukan lagi menjadi sebuah disiplin ilmu. Kajian secara fisiologis telah menjadi kepentingan dunia medis kedokteran dan penekanan pada dunia roh atau yang tidak kelihatan dalam diri manusia, telah menjadi keahlian para teolog. Kajian psikologis melihat beberapa aspek perilaku yang 
merupakan presentasi dari jiwa seseorang. Hal tersebut seperti kemampuan, sikap kerja dan kepribadian. Semua itu dapat di diagnosa dengan alat tes.

Kemampuan yang dimaksud mencakup daya nalar seseorang dalam memecahkan sebuah masalah, kemampuan dalam berhitung, pengetahuan secara umum dan lainᄀ-lain. Sikap kerja berkaitan dengan bagaimana kecepatan seseorang dalam kerja, ketelitian, daya tahan seseorang ketika dalam tekanan, ketekunan dan lain-lain. Kepribadian mencakup emosi, kepercayaan diri, penyesuaian diri, motivasi dan lain-lain.

Kajian psikologis sebagai ilmu disiplin ingin membantu memecahkan masalah mental manusia serta masalah kolektif manusia atau yang disebut masyarakat. Sehingga tidak hanya mengenai individu saja melainkan ada kaitannya dengan individu lainnya.

Manusia memang multi dimensi. Secara umum dan sederhana memang terdiri dari yang kelihatan, yaitu tubuh jasmani dan yang tidak kelihatan, yaitu alam roh dan jiwa (yang sering dipakai silih berganti dalam penulisan Perjanjian Lama).

Di dalam Perjanjian Baru ada perkembangan yang menarik dalam menganalisis keberadaan manusia. Adanya penguraian segenap hatimu, segenap jiwamu, segenap kekuatanmu, segenap akal budimu bukanlah suatu kebetulan tanpa makna. Dan keempatnya oleh Lukas dituliskan secara terpisah, yang sesungguhnya bisa juga menjadi suatu kajian tersendiri.

\section{DAFTAR PUSTAKA}

[1] Andaline, Z. V. (2017). STRATEGI COPING STRESS SINGLE MOTHER YANG MEMILIKI ANAK USIA DEWASA DENGAN DOWN SYNDROME.

[2] Baker, Charles F. A Dispensational Theology. Jakarta: Pustaka Alkitab Anugerah, 2009.

[3] Berkhof, Louis. Teologi Sistematika.Vol.2 Doktrin Manusia. Jakarta: Lembaga Reformed Injili Indonesia, 1994.

[4] Heath, W. Stanley. Psikologi yang Sebenarnya. Yogyakarta: CV. Andi

Offset,1995.
[5] Indra, Ichwei G. Teologi Sistematis: Pengetahuan Lanjutan Bagi Kaum Awam dan Anggota Gereja. Bandung: Lembaga Literatur Baptis, 2003.

[6] Juanda, J. (2016). Pengaruh Kelas Pendalaman Iman Anak Lebak Arum (Piala)

Terhadap Pertumbuhan Rohani Anak Usia 1114 Tahun Di Kompleks Perumahan Lebak Arum Surabaya. Journal Kerusso, 1(1), 51-56.

[7] Ladd, George Eldon. Teologi Perjanjian Baru. Jilid 2. Bandung: Kalam Hidup, 2013.

[8] Livingston, James C., Francis Schussler Fiorenza. Modern Christian Thought. New Jersey: Prentice-Hall, Inc, 1997.

[9] Meier, Paul D., Minirth, Frank B., \& Wichern, Frank. Introduction Psychology \& Counseling. United States of America: Baker Book House Company, 1982.

[10] Permana, Surja, et al. "Memorizing Bible Verses with the Association Method of Quantum Learning in Sunday School." Journal Didaskalia 2.1 (2019): 1-5.

[11] Prasetyo, Widi, et al. "Measuring the Quality of God's Servants According to Acts 6: 3 At the Surabaya City Tabernacle Pentecostal Church." Journal KERUGMA 2.1 (2019): 24-33.

[12] Ryrie, Charles C. Teologi Dasar 1. Yogyakarta: Yayasan ANDI, 1992.

[13] Sobur, Alex. Psikologi Umum. Cetakan ke-6 Ed: revisi. Bandung: CV. Pustaka Setia, 2016.

[14] Sumanto. Psikologi Umum. Yogyakarta: CAPS, 2014.

[15] Thiessen, Henry C. Teologi Sistematika. Malang: Gandum Mas, 2010. 